\title{
Putting Reversal Theory's Model of Four Domains of Experience in the Hot Seat
}

\author{
Etienne Mullet \\ Institute of Advanced Studies (EPHE), Paris, France \\ Lonzozou Kpanake \\ TelUQ, University of Quebec at Montreal \\ Ornheilia Zounon, Myriam Guedj, \\ and Maria Teresa Muñoz Sastre \\ University of Toulouse
}

\begin{abstract}
We present, in a synthetic way, the main findings from a series of ten studies in the domain of health psychology. All of these studies have inventoried motives to perform or not perform a given health-related behavior (e.g., consulting a physician) without postulating any a priori motivational structure. As a result, the whole set of studies allowed testing the capacity of reversal theory's model of four domains of experience to account for motivational data gathered in different settings but on the common ground of health-related behavior. From five to ten factors were found in each study, and all these factors were classifiable in one or other of the twelve categories offered by the structure of four domains of experience when transactions and relationships were considered in combination. All factors posited by reversal theory were found except one; the only factor that was not found at least once was of the pro-autic kind. In some cases, two factors of motives had to be classified under the same rubric, which led to the suggestion that the relationship domain may perhaps be extended. Overall, our findings suggest that the four-domain model, and its associated ten mental states, encompass and surpass previous theories of human motivation.
\end{abstract}

Keywords: reversal theory, motivation, health psychology

Reversal Theory (RT) is an exceptionally broad conceptual framework that has been used in a great diversity of studies conducted in a wide variety of domains in psychology: clinical psychology (e.g., Apter \& Smith, 1978; Martin, Kuiper, Olinger, \& Dobbin, 1987), criminology (e.g., Jones \& Heskin, 1988), educational psychology (e.g., Grewel \& Lafreniere, 2003), personality (e.g., Apter \& ApterDesselles, 1983; Lafreniere \& Cramer, 2006), psychopathology (e.g., Anderson \& Brown, 1987; O'Connell, Schwartz, Gerkovich, Bott, \& Shiffman, 2004), and, above all else, sport and exercise psychology (e.g., Kerr \& Males, 2011; Legrand, \& Thatcher, 2011; Thatcher, Kuroda, Legrand, \& Thatcher, 2011).

In the present paper we present, in a synthetic way, the main findings from a series of ten studies in the domain of health psychology. These studies are, of course, not the only ones in health psychology that have used RT as a theoretical

The paper is taken from the Ken Smith memorial lecture that was given at the 16th International Meeting of the Reversal Theory, Reims, July 2013. Correspondence concerning this article should be addressed to Etienne Mullet, 17bis, rue de Quefes, F-31830 Plaisance, France. E-mail: etienne.mullet@wanadoo.fr basis (see Apter \& Spirn, 1997; or Svebak, Ursin, Endresen, Hjelmen, \& Apter, 1991). What these ten studies have in common, however, is that they systematically inventoried motives to perform or not perform a given health-related behavior (e.g., consulting a physician) without postulating any a priori motivational structure. In other words, these studies tested the capacity of the RT's model of four domains of experience (Apter, 2001) to account for motivational data gathered in different settings on the common ground of healthrelated behavior (or non-behavior). As recently stated by Cramer (2013), it is timely to test RT (at least in one of its many aspects) using rigorous methods.

\section{The Ten Studies}

Table 1 shows the studies that were analysed. Four of these studies deal with medical consultation (consulting a generalist or an alternative practitioner, going to an emergency department or to the local hospital). The other studies involve surgery, organ donation, or aesthetics. Six studies were conducted in Western Europe, namely France, and four in Western Africa, namely Benin and Togo. One of these studies was not about motives but about preferences (end of life preferences). It was incorporated in the present review because its methodological structure was similar to that of 
Table 1

The Ten Studies

\begin{tabular}{|c|c|}
\hline Movtives for.. & Reference \\
\hline Consulting a physician & $\begin{array}{l}\text { Cottencin, A., Mullet, E., \& Sorum, P. Consulting a generalist: A systematic inventory of } \\
\text { motives. Unpublished manuscript. }\end{array}$ \\
\hline Consulting an alternative practitioner & $\begin{array}{l}\text { Cottencin, A., Mullet, E., \& Sorum, P. (2006). Consulting an alternative practitioner: A } \\
\text { systematic inventory of motives. Journal of Alternative and Complementary Medicine, 12, } \\
791-798 .\end{array}$ \\
\hline Bringing a child to PED & $\begin{array}{l}\text { Costet Wang, A., Claudet, I., Sorum, P. C., \& Mullet, E. Why do French parents bring their } \\
\text { children to the emergency department? Unpublished manuscript. }\end{array}$ \\
\hline Donating organs (post mortem) & $\begin{array}{l}\text { Guedj, M., Muñoz Sastre, M. T., \& Mullet, E. (2011). Donating organs: A theory-driven } \\
\text { inventory of motives. Psychology, Health } \mathcal{E} \text { Medicine, 16, 418-429. }\end{array}$ \\
\hline Bleaching one's skin & $\begin{array}{l}\text { Kpanake, L., Muñoz Sastre, M. T., Mullet, E. (2010). Skin bleaching among Togolese: A } \\
\text { systematic inventory of motives. Journal of Black Psychology, 38, 350-268. }\end{array}$ \\
\hline Not attending medical facilities & $\begin{array}{l}\text { Kpanake, L., Dassa, K. \& Mullet, E. (2009). Why most Togolese patients do not seek care for } \\
\text { malaria in health facilities: A theory-driven inventory of reasons. Psychology, Health } \mathcal{E} \\
\text { Medicine, 14, 502-510. }\end{array}$ \\
\hline Refusing surgery & $\begin{array}{l}\text { Zounon, O., Sorum, P., \& Mullet, E. Why people in Sub-Saharan countries are unwilling to } \\
\text { undergo surgical amputations? Unpublished manuscript. }\end{array}$ \\
\hline Not donating organs (post mortem) & $\begin{array}{l}\text { Guedj, M., Muñoz Sastre, M. T., \& Mullet, E. (2011). Donating organs: A theory-driven } \\
\text { inventory of motives. Psychology, Health } \mathcal{E} \text { Medicine, 16, 418-429. }\end{array}$ \\
\hline Refusing to donate blood & $\begin{array}{l}\text { Alinon, K., Gbati, K., Sorum, P. C., \& Mullet, E. (2013). Emotional-motivational barriers to } \\
\text { blood donation among Togolese adults: A structural approach. Transfusion Medicine, in press. }\end{array}$ \\
\hline End of life preferences & $\begin{array}{l}\text { Bonnin-Scaon, S., Muñoz Sastre, M. T., Chasseigne, G., Sorum, P. C., \& Mullet, E. (2009). } \\
\text { End-of-life preferences: A theory-driven inventory. International Journal of Aging and Human } \\
\text { Development, } 68,1-26 \text {. }\end{array}$ \\
\hline
\end{tabular}

the other studies. The approach implemented in these ten studies comprises five steps: four qualitative and one quantitative.

First step: Select a broad topic (usually a topic of societal relevance). Usually, the selected topic was brought to our attention by students or researchers interested in studying it. For example, in 2011, we decided to study the motives that led people in Togo not to donate their blood because our colleagues in Togo argued it was a timely health issue there and because, even to us Western Europeans, there was no doubt about the topic's societal relevance. Our reason for systematically choosing broad topics is that examining topics of this kind is likely to place us in good position to observe complex motivational structures.

Second step: Create a list of items that reflect the diversity of motives underlying the behavior. In each case, items were generated in the following way. Through an extensive review of the existing literature, we were usually able to make a provisional inventory of the motives or reasons for performing or not performing the behavior, motives that had already been reported in previous studies. Then, using the RT framework and, in particular, O'Connell's (1993) detailed categorization (see also O'Connell \& Apter, 1993), we were usually able to categorize, on an a priori basis, most of these motives as telic, paratelic, autocentric, and so on (see Table 2 ). This categorization usually led us to discover that some categories were empty even though credible motives corresponding to these categories could be imagined (e.g., proautic mastery motives). As a result, we were usually able to create additional sets of complementary items. Finally, we systematically conducted focus groups in which people were presented with the provisional list of items and asked to suggest new items. For example, because of the scarcity of scientific literature, it was only after several focus group sessions with lay people and patients living in Cotonou, Benin, in 2012 that we were able to develop a satisfying set of items expressing the possible motives underlying the rejection of surgical amputation of a limb. The common wording of all items (e.g., "One of the reasons why I have lightened my skin" in the skin bleaching study) was chosen to reflect the fact that several motives can be operating at the same time or at different times for the same person.

Third step: Gather as much data as possible. Having large pools of participants was necessary because we wanted to apply rigorous procedures that are now classical in questionnaire analysis: (a) examine the structure of the responses using one part of the sample and (b) test the robustness of this structure using the remaining part of it. In other words, 
Table 2

Reversal Theory's Model of Four Domains of Experience

\begin{tabular}{|c|c|c|}
\hline Domain & State & Characteristic \\
\hline \multirow[t]{2}{*}{ Goals and Means } & Telic & Focusing on goals and achievement with a serious attitude \\
\hline & Paratelic & Focusing on the activity itself and on present moment with a playful attitude \\
\hline \multirow[t]{2}{*}{$\begin{array}{l}\text { Rules and } \\
\text { Constraints }\end{array}$} & Conformist & $\begin{array}{l}\text { Following social codes, rules and laws; showing respect or obedience; adopting a conventional } \\
\text { attitude }\end{array}$ \\
\hline & Negativist & $\begin{array}{l}\text { Opposing social expectations and rules; expressing hostility or dissidence; adopting an } \\
\text { unconventional attitude }\end{array}$ \\
\hline \multirow[t]{2}{*}{ Transactions } & Mastery & Trying to dominate people, things or situations \\
\hline & Sympathy & Feeling affection toward other people or things \\
\hline \multirow[t]{4}{*}{ Relationships } & Autocentric & Being the focus of other's concerns and interests \\
\hline & Intra-Autic & Focusing on one's own concerns and interests \\
\hline & Allocentric & Identifying with and focusing on others' needs and interests \\
\hline & Pro-Autic & Living through (usually) powerful or sympathetic others \\
\hline
\end{tabular}

exploratory factor analysis and confirmatory factor analysis were, each time it was feasible, applied on separate sets of data.

Fourth step: Do the statistical analyses. Statistical analysis was the fourth step, the quantitative one. It usually involves exploratory factor analysis, and confirmatory factor analysis.

Fifth step: Collectively interpret the factors that issue from the analyses. In some cases, interpretation was straightforward. For example, in the study on organ donation, a factor explaining an important part of the variance loaded several items, among them (a) my religion or my philosophical views encourages me to do so, (b) everybody in my family would donate organs, (c) it is a more and more common decision among people, and (d) it is a civic act. It was not difficult to label this factor Humanistic or Religious Duty: a factor that corresponded to the Conformist pole of the Rules construct.

In other cases, interpretation was only achieved after collective brainstorming, by considering the whole set of factors in conjunction instead of considering each factor independently or by combining the domains of Transactions and Relationships. For example, in the study on the motives not to seek care for malaria in health care facilities, a factor explaining an important part of the variance loaded several items with high mean ratings, among them (a) health caregivers behave aggressively, (b) health centers are unhealthy places, (c) health caregivers try to bribe people, and (d) health caregivers do not show empathy. We labelled this factor Caregivers' Unethical Behavior, and we finally realized that it was an expression of our participants' alloic mastery concerns: not placing oneself in the hands of people who are not necessarily benevolent and who would not respect your autonomy, two basic principles of bioethics.

\section{The Motives that Were Found}

Table 3 shows examples of items that loaded factors interpreted as being of the telic or paratelic types. Getting appropriate treatment, wishing one's child to be quickly treated, finding a job, or leaving one's affairs in order are undeniably motives that express the participants' willingness to achieve, in a more or less close future, a serious objective. In contrast, the items in the right column tend to express motives that are more related to the immediate present. Consulting in order to be comforted is, in a sense, consulting for consulting; that is, it is the consultation in itself that is the objective. In addition, the consultation is expected to be a pleasant experience.

Table 4 shows examples of items that loaded factors interpreted as being of the conformist or negativist types. "I was supposed to do this at regular intervals", "Most of my family members did it", or "It's something that goes against natural law" undeniably reflect conformist concerns. By contrast, wishing to annoy one's family, considering that the family physician's diagnosis was wrong, or not feeling concerned by others' health problems undeniably reflect negativist concerns.

Table 5 shows examples of items that loaded factors interpreted as being of the Autic-Mastery type. In particular, "to not be kept alive by artificial means" at the time of dying certainly expresses the wish not to lose one's physical autonomy, and "to be able to oppose every attempt at invasive treatment" expresses the wish not to lose one's personal autonomy.

Table 6 shows examples of items that loaded factors interpreted as being of the Autic-Sympathy type. In particular, wanting to have a good image of the self and wanting to attract people's attention clearly express sympathy-type concerns: sympathy towards the self (i.e., self-esteem) and sympathy from others. 
Table 3

Examples of Items Loading on the Telic Factor or the Paratelic Factor

\begin{tabular}{lll}
\hline Motives for... & Telic & Paratelic \\
\hline Consulting a physician & The physician would tell me what was wrong with & In order to be comforted \\
me & To get appropriate treatment & In order to be comforted \\
Bringing a child to PED & I wished my child's pain to be quickly treated & $\begin{array}{l}\text { PED has all kinds of medical } \\
\text { equipment in place }\end{array}$ \\
$\begin{array}{l}\text { Donating organs (post mortem) } \\
\text { Skin Bleaching }\end{array}$ & My funerals would be paid & Because a lighter skin is so beautiful \\
Not attending medical facilities & I wanted to more easily find a job & \\
Refusing to undergo surgical amputation & Medical care is too expensive & It cannot improve my health's state \\
Not donating organs (post mortem) & & \\
Refusing to donate blood & I'm afraid of having a health problem as a result of & \\
transfusion & To leave your affairs in order & To be able still to laugh a little \\
\hline
\end{tabular}

Note $:$ PED = pediatric emergency department

Table 4

Examples of Items Loading on the Conformist Factor or the Negativist Factor

\begin{tabular}{|c|c|c|}
\hline Motives for... & Conformist & Negativist \\
\hline Consulting a physician & I was supposed to do this at regular intervals & In order to annoy my family \\
\hline Consulting an alternative practitioner & The drugs prescribed are always natural* & In order annoy my family \\
\hline Bringing a child to PED & & $\begin{array}{l}\text { I considered that the diagnosis was } \\
\text { wrong }\end{array}$ \\
\hline Donating organs (post mortem) & It is a common decision among people & \\
\hline Skin bleaching & Most of my family members did it* & $\begin{array}{l}\text { I wanted to have my ethnic } \\
\text { background forgotten }\end{array}$ \\
\hline Not attending medical facilities & My family is used to treat malaria & $\begin{array}{l}\text { I have serious reservations about the } \\
\text { quality of care }\end{array}$ \\
\hline Refusing to undergo surgical amputation & & $\begin{array}{l}\text { I'm not confident in physicians' } \\
\text { dedication }\end{array}$ \\
\hline Not donating organs (post mortem) & We must preserve the integrity of the corpus & I'm not concerned by others' problems \\
\hline Refusing to donate blood & It's something that goes against natural law & $\begin{array}{l}\text { I'm afraid that blood will be employed } \\
\text { for speculative ends }\end{array}$ \\
\hline End of life preferences & $\begin{array}{l}\text { To feel at peace with your God. To have a feeling } \\
\text { of personal accomplishment }\end{array}$ & \\
\hline
\end{tabular}

Note $:$ PED = pediatric emergency department

Table 7 shows examples of items that loaded a factor interpreted as being of the Alloic-Mastery type. Not wanting to consult medical facilities because health caregivers behave aggressively, not wanting to undergo surgery out of fear of hospitals and medical staff, and not wanting to donate blood because of fear of nurses are clear instances of unwillingness to place oneself under other people's control. No factor expressing pro-autic mastery views was found.

Finally, Table 8 shows examples of items that loaded factors interpreted as being of the Alloic-Sympathy type. The items loading the pro-autic factor were remarkable (in particular, "I would be happy to live on through somebody else"). The other items clearly reflected concern about and sympathy for others.

sectionA Synthesis

Table 9 shows the main findings of the ten studies in terms of number of factors and their interpretation using RT's conceptual framework. As can be observed, from five to ten factors were found each time, and all these factors were classifiable in one or other of the twelve categories offered by 
Table 5

Examples of Items Loading on the Intra-Autic Mastery Factor or the Autocentric Mastery Factor

\begin{tabular}{lll}
\hline Motives for... & Intra-Autic Mastery & Autocentric Mastery \\
\hline Consulting a physician & $\begin{array}{l}\text { To have a better understanding of the illness I } \\
\text { was suffering from } \\
\text { To get a treatment that stimulate my } \\
\text { intelligence }\end{array}$ & \\
$\begin{array}{l}\text { Bringing a child the ED } \\
\text { Donating organs (post mortem) }\end{array}$ & & I wanted to be considered by others as an \\
Skin Bleaching & important person \\
Not attending medical facilities & It would deplete my spiritual strength & I wanted to keep control over the care \\
Refusing to undergo surgical amputation & It can considerably alter my physical \\
Not donating organs (post mortem) & appearance & \\
Recause of lack of personal courage & To not be kept alive by artificial means & To be able to oppose every attempt at \\
End of life preferences & & invasive treatment
\end{tabular}

Note: $\mathrm{PED}=$ pediatric emergency department

Table 6

Examples of Items Loading on the Intra-Autic Sympathy Factor or the Autocentric Sympathy Factor

\begin{tabular}{|c|c|c|}
\hline Motives for... & Intra-Autic Sympathy & Autocentric Sympathy \\
\hline \multicolumn{3}{|l|}{ Consulting a physician } \\
\hline \multicolumn{3}{|l|}{ Consulting an alternative practitioner } \\
\hline Bringing a child to PED & & $\begin{array}{l}\text { I wished my child to have nothing to } \\
\text { reproach me for }\end{array}$ \\
\hline Donating organs (post mortem) & & $\begin{array}{l}\text { I would attract the positive consideration of } \\
\text { close others }\end{array}$ \\
\hline Skin Bleaching & I wanted to have a good image of myself & I wanted to attract eyes on me \\
\hline Not attending medical facilities & & Health caregivers are not reassuring persons \\
\hline Refusing to undergo surgical amputation & I would lose my personal identity & $\begin{array}{l}\text { I would lose others' consideration and } \\
\text { affection }\end{array}$ \\
\hline Not donating organs (post mortem) & & $\begin{array}{l}\text { The receiver will not know in advance that } \\
\text { I'm the donor }\end{array}$ \\
\hline Refusing to donate blood & & $\begin{array}{l}\text { No gratitude expected from health } \\
\text { professionals }\end{array}$ \\
\hline End of life preferences & To be able to obtain adequate pain treatment & $\begin{array}{l}\text { To have a family member at the bedside until } \\
\text { the end }\end{array}$ \\
\hline
\end{tabular}

Note: $\mathrm{PED}=$ pediatric emergency department

the structure of four domains of experience when transactions and relationships were considered in combination. Of course, classification was largely subjective, but, as stated above, it was achieved through mutual consensus. Note also that, sometimes, two empirically separable factors had to be classified under the same mental state (see the donating organs study).
Table 10 shows the mean level of endorsement for each factor. Three types of motives to perform or not perform a health-related behavior were more frequently endorsed to a high level than others: telic (in six studies the level of endorsement was higher than 3), conformist (four studies), and alloic sympathy (three studies). 
Table 7

Examples of Items Loading on the Allocentric Mastery Factor

\begin{tabular}{|c|c|c|}
\hline Motives for... & Pro-Autic Mastery & Allocentric Mastery \\
\hline \multicolumn{3}{|l|}{ Consulting a physician } \\
\hline \multicolumn{3}{|l|}{ Consulting an alternative practitioner } \\
\hline Bringing a child to PED & & The family physician did not respond to my call \\
\hline \multicolumn{3}{|l|}{ Donating organs (post mortem) } \\
\hline \multicolumn{3}{|l|}{ Skin Bleaching } \\
\hline Not attending medical facilities & & Health caregivers behave aggressively \\
\hline Refusing to undergo surgical amputation & & I fear of hospitals and medical staff \\
\hline \multicolumn{3}{|l|}{ Not donating organs (post mortem) } \\
\hline Refusing to donate blood & & I'm afraid of nurses \\
\hline End of life preferences & & $\begin{array}{l}\text { Being forgiven by persons whom you might have wronged } \\
\text { during your life }\end{array}$ \\
\hline
\end{tabular}

Note: $\mathrm{PED}=$ pediatric emergency department

Table 8

Examples of Items Loading on the Pro-Autic Sympathy Factor or the Allocentric Sympathy Factor

\begin{tabular}{|c|c|c|}
\hline Motives for... & Pro-Autic Sympathy & Allocentric Sympathy \\
\hline Consulting a physician & & Because my spouse insisted that I do it. \\
\hline Consulting an alternative practitioner & & In order to reassure someone who was worried about me \\
\hline Bringing a child to PED & & $\begin{array}{l}\text { I was no longer able to put up with seeing my child with an } \\
\text { elevated fever }\end{array}$ \\
\hline Donating organs (post mortem) & $\begin{array}{l}\text { I would be happy to live on } \\
\text { through somebody else }\end{array}$ & $\begin{array}{l}\text { There are many persons waiting for an organ. My organs } \\
\text { would benefit a member of my family }\end{array}$ \\
\hline Skin Bleaching & & For my partner's pleasure \\
\hline Not attending medical facilities & & I didn't want my family to become too concerned \\
\hline \multicolumn{3}{|l|}{ Refusing to undergo surgical amputation } \\
\hline Not donating organs (post mortem) & & I would not like to hurt several members of my family \\
\hline \multicolumn{3}{|l|}{ Refusing to donate blood } \\
\hline End of life preferences & & To remain useful to others until the end \\
\hline
\end{tabular}

Note: $\mathrm{PED}=$ pediatric emergency department

\section{Did the Four-Domain Model Pass the Test?}

What pattern of findings could be considered as falsifying the four-domain model and its associated ten mental states? In our view, it would be a pattern of findings consistent with a more restricted theory of motivation. For example, if across the ten studies, only three factors had always been foundfactors close in meaning to (a) the telic factor shown in Table 3 , (b) the autocentric mastery factor shown in Table 5, and (c) the autocentric sympathy factor shown in Table 6-then RT would be considered as falsified, and conversely, McClelland's (1985) theory of human motivation would be largely supported. McClelland's theory posits in effect the existence of only three basic human needs: need of achievement (alias, telic), need for power (alias, autocentric mastery), and need of affiliation (alias, autocentric, and perhaps allocentric, sympathy).

In the same vein, if across these studies, only two factors had always been found-factors close in meaning to (a) the telic factor, as in the previous case, and (b) the paratelic factor shown in Table 3-then RT would be considered as falsified, and conversely, Ryan and Deci's (2000) theory of human motivation would be largely supported. Ryan and Deci's theory posits in effect the existence of only two broad human motivations: intrinsic (alias, paratelic) and extrinsic (alias, telic).

In the present review, we are far from having found a systematic three- or two-factor structure across studies. On the contrary, the findings would rather suggest that the fourdomain model, and its associated ten mental states, encom- 
Table 9

Number of Empirically Separable Factors Found in Each Study

\begin{tabular}{|c|c|c|c|c|c|c|c|c|c|c|c|c|}
\hline \multirow[b]{2}{*}{ Studies } & \multirow[b]{2}{*}{$\mathrm{T}$} & \multirow[b]{2}{*}{$\mathrm{P}$} & \multirow[b]{2}{*}{$\mathrm{C}$} & \multirow[b]{2}{*}{$\mathrm{N}$} & \multirow[b]{2}{*}{ IM } & \multicolumn{2}{|c|}{ Autic } & \multirow[b]{2}{*}{ AS } & \multicolumn{3}{|c|}{ Alloic } & \multirow[b]{2}{*}{ Total } \\
\hline & & & & & & $\mathrm{AM}$ & IA & & $\operatorname{Pr}$ & $\mathrm{AM}$ & AS & \\
\hline Consulting a physician & $\mathrm{x}$ & $\mathrm{x}$ & $\mathrm{x}$ & $\mathrm{x}$ & $\mathrm{x}$ & & & & & & $\mathrm{x}$ & 6 \\
\hline Consulting an alternative practitioner & $\mathrm{x}$ & $\mathrm{x}$ & $\mathrm{x}$ & $\mathrm{x}$ & $\mathrm{x}$ & & & & & & $\mathrm{x}$ & 6 \\
\hline Bringing a child to PED & $\mathrm{x}$ & $\mathrm{x}$ & & $\mathrm{x}$ & & & & $\mathrm{x}$ & & $\mathrm{x}$ & $\mathrm{x}$ & 6 \\
\hline Donating organs (post mortem) & $\mathrm{x}$ & & $\mathrm{x}$ & & & & & $\mathrm{x}$ & $\mathrm{x}$ & & $\mathrm{xx}$ & 6 \\
\hline Skin Bleaching & $\mathrm{x}$ & $\mathrm{x}$ & $\mathrm{x}$ & $\mathrm{x}$ & & $\mathrm{x}$ & $\mathrm{x}$ & $\mathrm{x}$ & & & $\mathrm{x}$ & 8 \\
\hline Subtotal & 5 & 4 & 4 & 4 & 2 & 1 & 1 & 3 & 1 & 1 & 6 & \\
\hline Not attending medical facilities & $\mathrm{x}$ & & $\mathrm{x}$ & $\mathrm{x}$ & & $\mathrm{x}$ & & $\mathrm{x}$ & & $\mathrm{x}$ & $\mathrm{x}$ & 7 \\
\hline Refusing to undergo surgical amputation & $\mathrm{x}$ & & & $\mathrm{x}$ & $\mathrm{x}$ & & $\mathrm{x}$ & $\mathrm{x}$ & & $\mathrm{x}$ & & 6 \\
\hline Not donating organs (post mortem) & & & $\mathrm{x}$ & $\mathrm{x}$ & $\mathrm{x}$ & & & $\mathrm{x}$ & & & $\mathrm{x}$ & 5 \\
\hline Refusing to donate blood & $\mathrm{x}$ & & $\mathrm{x}$ & $\mathrm{x}$ & $\mathrm{x}$ & & & $\mathrm{x}$ & & $\mathrm{x}$ & & 6 \\
\hline Subtotal & 3 & 0 & 3 & 4 & 3 & 1 & 1 & 4 & 0 & 3 & 2 & \\
\hline End of life preferences & $\mathrm{x}$ & $\mathrm{x}$ & $\mathrm{xx}$ & & $\mathrm{x}$ & $\mathrm{x}$ & $\mathrm{x}$ & $\mathrm{x}$ & & $\mathrm{x}$ & $\mathrm{x}$ & 10 \\
\hline Total & 9 & 5 & 9 & 8 & 6 & 3 & 3 & 8 & 1 & 5 & 9 & \\
\hline
\end{tabular}

Note: $\mathrm{T}=$ Telic, $\mathrm{P}=$ Paratelic, $\mathrm{C}=$ Conformist, $\mathrm{N}=$ Negativist, $\mathrm{I}=$ Intra, $\mathrm{M}=$ Mastery, $\mathrm{S}=$ Sympathy, $\mathrm{Pr}=\operatorname{Pro}$

Table 10

Mean Levels of Endorsement for Each Factor of Motives. Number of Factors with a Level of Endorsement Higher than 3 (on a 0-10 Scale)

\begin{tabular}{|c|c|c|c|c|c|c|c|c|c|c|c|}
\hline \multirow[b]{2}{*}{ Studies } & \multirow[b]{2}{*}{$\mathrm{T}$} & \multirow[b]{2}{*}{$\mathrm{P}$} & \multirow[b]{2}{*}{$\mathrm{C}$} & \multirow[b]{2}{*}{$\mathrm{N}$} & \multicolumn{4}{|c|}{ Autic } & \multicolumn{3}{|c|}{ Alloic } \\
\hline & & & & & IM & $\mathrm{AM}$ & IA & AS & $\operatorname{Pr}$ & $\mathrm{AM}$ & AS \\
\hline Consulting a physician & 6 & 1 & 5 & 1 & 3 & & & & & & 2 \\
\hline Consulting an alternative practitioner & 6 & 3 & 5 & 1 & 1 & & & & & & 1 \\
\hline Bringing a child to PED & 6 & 5 & & 1 & & & & 1 & & 1 & 3 \\
\hline Donating organs (post mortem) & 2 & & 3 & & & & & 3 & 4 & & 8,7 \\
\hline Skin Bleaching & 5 & 7 & 6 & 3 & & 7 & 5 & 6 & & & 2 \\
\hline Not attending medical facilities & 7 & & 6 & 1 & & 1 & & 1 & & 6 & 4 \\
\hline Refusing to undergo surgical amputation & 2 & & 1 & 3 & & & 6 & 3 & & 3 & \\
\hline Not donating organs (post mortem) & & & 3 & 1 & 4 & & & 2 & & & 1 \\
\hline Refusing to donate blood & 4 & & 2 & 5 & 5 & & & 2 & & 2 & \\
\hline$n(M>3)$ & 6 & 2 & 4 & 1 & 2 & 1 & 2 & 1 & 1 & 1 & 3 \\
\hline
\end{tabular}

Note: $\mathrm{T}=$ Telic, $\mathrm{P}=$ Paratelic, $\mathrm{C}=$ Conformist, $\mathrm{N}=$ Negativist, $\mathrm{I}=$ Intra, $\mathrm{M}=$ Mastery, $\mathrm{S}=$ Sympathy, $\mathrm{Pr}=\mathrm{Pro}$

pass and surpass the theories of McClelland and of Ryan and Deci (see also Alderfer, 1989).

As it is apparent in Tables 3-8, all the possible factors posited by RT were never found in any particular study. Does this observation invalid the whole framework? RT is a theory about human motivation in general; in Cramer's (2013) words, it is a comprehensive theory. It is not a specific theory about human motivation in health care settings. Nor is it an even more specific theory about the motives to donate organs or to refuse to donate blood. As a result, the strength and weakness of RT must be assessed across a large number of studies examining people's motives as they are expressed in a wide variety of daily life situations.
In the present set of ten studies, all factors posited by RT were found except one, and the only factor that was not found at least once was of the pro-autic kind. We have, however, no definite reason to think that this factor is really inexistent in general. For a factor to appear in factor analysis, items corresponding to this factor must have been created by the experimenter and included in the questionnaire. In addition, the particular motives at work naturally depend on the situation. Occasionally, a specific situation will not evoke one of the types of motives. Remember that the ten studies analyzed in the present review were all about health-related behavior.

A common reason why a factor does not appear is experimenter's shortsightedness. Our personal experience tells us that RT is good medicine to shortsightedness: It forces ex- 
perimenters to consider no less than ten (or twelve) kinds of motives at the time of creating their material. For instance, the pro-autic factor found in the organ donation study would never have been found if we had not been aware of the possibility of pro-autic motives (see also Giraudeau, Chasseigne, Apter, \& Mullet, 2007; Lakhdar, Vinsonneau, Apter, \& Mullet, 2007; Makris \& Mullet, 2009; Vera Cruz \& Mullet, 2013). In other words, at the time of assessing the validity of a theory, one must not hesitate to be as harsh with the experimenter who conducted the empirical studies as this experimenter was prepared to be harsh with the theory itself (Cramer, 2013).

It may also be concerning that in some cases, two factors of motives had to be classified under the same rubric. Does this observation invalid the basic meaning of the mental states? In the organ donation study, as already stated above, two separate allocentric sympathy factors were found: one that was labeled Gift of Life (e.g., "it could improve the quality of life of patients"), and another labeled Close Others (e.g., "my organs would benefit a member of my family").

Factor analysis blindly "groups together" items that covary. What makes items co-vary may depend on different things. In the case under examination, two sources of co-variation were obviously present: the nature of the motive (alloic) and the beneficiaries of the gift (either family members or anybody else). In RT, the relationships domain coarsely distinguishes the self from the non-self. The question is, might we agree to a revised version of the relationships domain, which would more finely distinguish the self from close others and close others from the rest of the world? People from individualist cultures, for whom the self is clearly identifiable and distinct from the non-self, are likely to think not. But people from collectivistic cultures, who tend to think of themselves as members of limited communities (the extended family, see Triandis, 1995), may think yes. In the study of blood non-donation in Togo, most people were unwilling to donate blood except to their children or close others. In other words, they manifested a kind of bounded allocentric sympathy that the RT four-domain model is presently unable to account for.

Also, interpreting some factors that arose from the analyses was only possible on the condition that we agreed to merge two domains, namely transactions and relationships (e.g., the factor called Respecting family's wishes in the organ donation study). Does this practical necessity invalid the basic meaning of RT domains of experience? We think not. According to RT, a given behavior is, most of the time, driven by a set of motives that act simultaneously (Apter, 2001). What this finding indicates is that transactions-type motives and relationships-type motives tend very frequently to occur together.

Furthermore, from the point of view of the researcher who creates the items, if it is, in most studies, not very difficult to think of pure conformist items or pure telic items, it is always very difficult to think of pure allocentric items or pure sympathy items. This is because sympathy, for instance, is always expressed towards somebody or something: the self, the family, or the whole world. Sympathy and mastery are by essence dyadic constructs: They absolutely need a relationship to someone (including the self) or something else to make sense.

In ending, we must emphasize that only one aspect of RT has been put in the hot seat in this review: the four-domain model. As stressed by Cramer (2013), another basic RT construct must urgently be examined: the eponym; that is, Reversals.

\section{References}

Alderfer, C. P. (1989). Theories reflecting my personal experience and life development. Journal of Applied Behavioral Science, 25, 351-365.

Alinon, K., Gbati, K., Sorum, P. C., \& Mullet, E. (2013). Emotional-motivational barriers to blood donation among Togolese adults: A structural approach. Transfusion Medicine, in press.

Anderson, G., \& Brown, R. I. F. (1987). Some applications of Reversal Theory to the explanation of gambling and gambling addictions. Journal of Gambling Behavior, 3, 179-189.

Apter, M. J. (2001) (Ed.). Motivational styles in everyday life: A guide to Reversal Theory. Washington, DC: American Psychological Association.

Apter, M. J., \& Apter-Desselles, M. L. (1993). The personality of the patient: Going beyond the trait concept. Patient Education and Counseling, 22, 107-114.

Apter, M. J., \& Smith, K. C. P. (1978). Sexual dysfunction: depression, anxiety and the reversal theory - Part 1. British Journal of Sexual Medicine, 5, 23-26.

Apter, M. J., \& Spirn, N. (1997). Motives for donating blood. In S. Svebak \& M. J. Apter (Eds.), Stress and health: A reversal theory perspective (pp. 145-156). Washington D.C.: Taylor \& Francis.

Bonnin-Scaon, S., Muñoz Sastre, M. T., Chasseigne, G., Sorum, P. C., \& Mullet, E. (2009). End-of-life preferences: A theory-driven inventory. International Journal of Aging and Human Development, 68, 1-26.

Costet Wang, A., Claudet, I., Sorum, P. C., \& Mullet, E. Why do French parents bring their children to the emergency department? Unpublished manuscript.

Cottencin, A., Mullet, E., \& Sorum, P. (2006). Consulting an alternative practitioner: A systematic inventory of motives. Journal of Alternative and Complementary Medicine, 12, 791-798.

Cottencin, A., Mullet, E., \& Sorum, P. Consulting a generalist: A systematic inventory of motives. Unpublished manuscript. 
Cramer, K. M. (2013). Six criteria of a viable theory: Putting Reversal Theory to the test. Journal of Motivation, Emotion, and Personality, 1, 9-16.

Giraudeau, C., Chasseigne, G, Apter, M. J., \& Mullet, E. (2007). Adult's lay views about intelligence: A Reversal Theory approach. Personality and Individual Differences, 42, 169-179.

Grewel, P. K., \& Lafreniere, K. D. (2003). Coping with academic failure: The effects of telic and paratelic states. Guidance and Counselling, 18, 101-110.

Guedj, M., Muñoz Sastre, M. T., \& Mullet, E. (2011). Donating organs: A theory-driven inventory of motives. Psychology, Health $\mathcal{E}$ Medicine, 16, 418-429.

Jones, R. S. P., \& Heskin, K. J. (1988). Towards a functional analysis of delinquent behavior: A pilot study. Counselling Psychology Quarterly, 1, 35-42.

Kerr, J.H. \& Males, J.R. (2011). Experiencing aggression in sport: Insights from a lacrosse world championship tournament. Sport and Exercise Psychology Review, 7, 26-33.

Kpanake, L., Dassa, K. \& Mullet, E. (2009). Why most Togolese patients do not seek care for malaria in health facilities: A theory-driven inventory of reasons. Psychology, Health $\mathcal{E}$ Medicine, 14, 502-510.

Kpanake, L., Muñoz Sastre, M. T., Mullet, E. (2010). Skin bleaching among Togolese: A systematic inventory of motives. Journal of Black Psychology, 38, 350-268.

Lafreniere, K. D., \& Cramer, K. M. (2006). Examining Reversal Theory measures in relation to NEO personality dimensions and consideration of future consequences. Personality and Individual Differences, 40, 1387-1397.

Lakhdar, M, Vinsonneau, G., Apter, M. J., \& Mullet, E. (2007). Conversion in Islam among French adolescents and adults: A systematic inventory of motives. International Journal for the Psychology of Religion, 17, 1-15.

Legrand, F.D., \& Thatcher, J. (2011) Acute mood responses to a 15-minute long walking session at self-selected intensity: Effects of an experimentally - induced telic or paratelic state. Emotion, 11, 1040-1045.

Makris, I., \& Mullet, E. (2009). A systematic inventory of motives for becoming an orchestra conductor: A prelim- inary study. Psychology of Music, 37, 443-458. Martin, R. A., Kuiper, N. A., Olinger, L. J., \& Dobbin, J. (1987). Is stress always bad?: Telic versus paratelic dominance as a stress moderating variable. Journal of Personality and Social Psychology, 53, 970-982.

McClelland, D. (1985). Human motivation. Cambridge: Cambridge University Press.

O'Connell, K. A. (1993). A lexicon for the mastery/sympathy and autic/alloic states. In J. H. Kerr, S. Murgatroyd \& M. J. Apter (Eds.), Advances in Reversal Theory (pp. 53-66). Amsterdam: Swets \& Zeitlinger.

O’Connell, K. A., \& Apter, M. J. (1993). Mastery and sympathy: Conceptual elaboration of the transactional states. In J. H. Kerr, S. Murgatroyd \& M. J. Apter (Eds.), Advances in Reversal Theory (pp. 41-52). Amsterdam: Swets \& Zeitlinger.

O’Connell, K.A., Schwartz, J.E., Gerkovich, M.M., Bott, M.J. \& Shiffman, S. (2004) Playful and rebellious states vs. negative affect in explaining the occurrence of temptations and lapses during smoking cessation. Nicotine and Tobacco Research, 4, 661-674.

Ryan, R. M., \& Deci, E. L. (2000). Intrinsic and extrinsic motivations: Classic definitions and new directions. Contemporary Educational Psychology, 25, 54-67.

Svebak, S., Ursin, H., Endresen, I., Hjelmen, A. M., \& Apter, M. J. (1991). Back pain and the experience of stress, efforts and moods. Psychology and Health, 5, 307-314.

Thatcher, J., Kuroda, Y., Legrand, F. D., \& Thatcher, R. (2011). Stress responses during aerobic exercise in relation to motivational dominance and state. Journal of Sports Sciences, 29, 299-306.

Triandis, H. C. (1995). Individualism and collectivism. Boulder, CO: Westview.

Vera Cruz, G., \& Mullet, E. (2013). The practice of puxapuxa among Mozambican women: A systematic inventory of motives. Journal of Sex Research, in press.

Zounon, O., Sorum, \& Mullet, E. Why people in SubSaharan countries are unwilling to undergo surgical amputations? Unpublished manuscript. 